\title{
Evaluation of the sprinkler irrigation system in the gardens of Koya University
}

\author{
Anwer Hazim D. \\ Geotechnical Department, Faculty of Engineering, Koya University, \\ Kurdistan region of Iraq
}

\begin{abstract}
This project includes analyzing the problem of surface runoff water losses in the Koya University gardens. We started with selecting a flat rectangular area $7.5 * 10 \mathrm{~m}$ in the garden near the registration office that was irrigated by a sprinkler irrigation system. The dimension of the water collection unit was $1.25 * 1.25 \mathrm{~m}$, with an operating system duration of 30 minutes. By measuring the depths of water in the cans and comparing with the volume of water output, we find the difference due to evaporation, spray losses and surface runoff, i.e. the total water output of the sprinkler divided into four parts infiltration, surface runoff, evaporation, spray for controlling surface runoff we measured soil infiltration and we find that the rate of net water reaching the soil surface is more than the basic infiltration rate.
\end{abstract}

Keywords: evaluation irrigation, assessment, sprinkler irrigation, irrigation uniformity, irrigation efficiency.

\section{Introduction}

Irrigation is an artificial application of water to the soil through various systems of tubes, pumps, and sprays. Irrigation is normally used in areas where rainfall is fluctuated or dry conditions or drought

In this type of irrigation water is applied to all field by means of rotating sprinklers or mini-sprinklers connected to a pressurized pipe system. Sprinkler spread water over a radius of 2 to $100 \mathrm{~m}$ as depending on design. The pipe system supplying the sprinklers can be permanent, movable, portable, or a combination of the three, and the system can be operated either automatically or semi-automatically. Some sprinklers can also be hidden below ground level, if 
aesthetics is a concern and pop up in response to increased water pressure. This type of system is commonly used in lawns, golf courses, cemeteries, parks, and other turf areas. Sprinklers may also be mounted on movable platforms connected to the water source by a hose. At the high-tech end, computerized, automatically moving wheeled systems may irrigate large areas.

In the sprinkler method of irrigation, water is sprayed into the air and allowed to fall on the ground surface somewhat resembling rainfall. The spray is developed by the flow of water under pressure through small orifices or nozzles. The pressure is usually obtained by pumping. With a careful selection of nozzle sizes, operating pressure and sprinkler spacing the amount of irrigation water required to refill the crop root zone can be applied nearly uniform at the rate to suit the infiltration rate of soil.

\section{Field work sprinkler test}

- We choose $7.50 * 10 \mathrm{~m}$ area (as shown in fig. 1) in the garden in Koya city that is near to the College of Science.

- We divided the cans in each square by dimension of $1.25 \mathrm{~m}$ by $1.25 \mathrm{~m}$ in the chosen area. Each can has the same diameter and the same depth; it means they have the same area (as shown in fig. 1).

- $\quad$ The garden has four sprinklers in each corner of the chosen area.

- $\quad$ The time working of sprinkler is 30 minutes (as shown in fig. 2).

After 30 minutes we switch off the sprinkler and read the depth of water in each cone by using ruler (as shown in fig. 2).

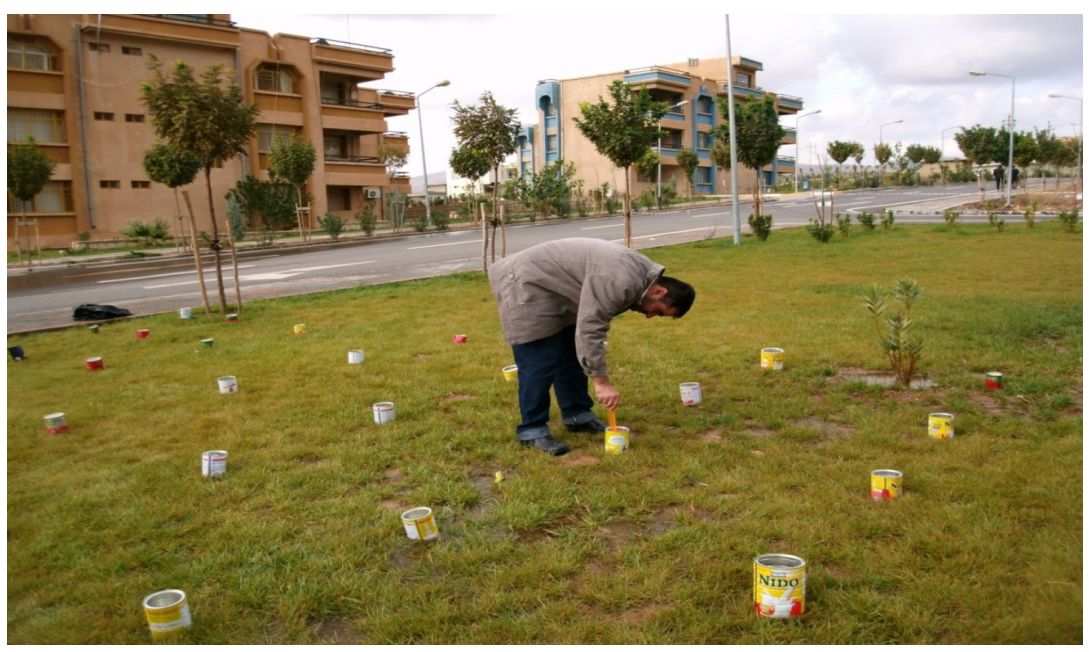

Figure 1: $\quad$ Measuring water depth in cans. 
First International Symposium on Urban Development: Koya as a Case Study 171

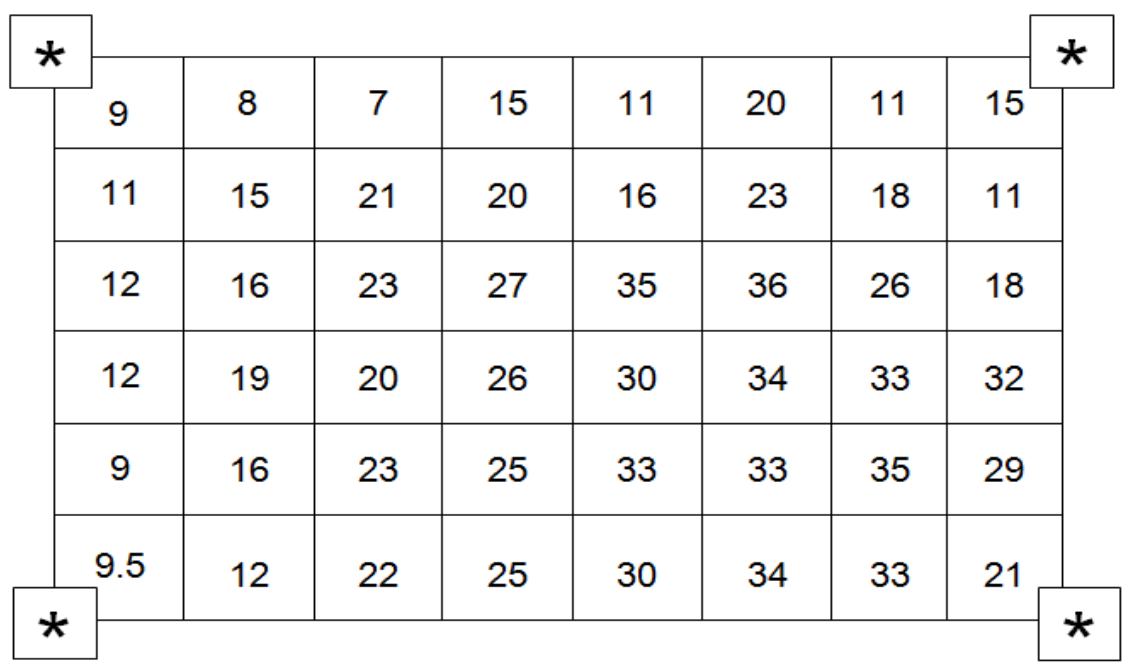

Figure 2: Depths of water in the cans.

\section{Calculation for determining coefficient uniformity}

$$
C u=\left(1-\frac{\sum x_{i}-\bar{x}}{n \bar{x}}\right) \times 100 \Longrightarrow \bar{x}=\frac{\sum x_{i}}{n}
$$

Where:

$\mathrm{Cu}$ : Coefficient of uniformity

n: Number of Cone

$x_{i}$ : Depth of water in Cone

$\bar{x}$ : Middle of the depth of water in Cone

$$
\begin{aligned}
& \Longrightarrow \bar{x}=\frac{1019.5}{48}=21.2395 \mathrm{~mm} \\
& \Longrightarrow C u=\left(1-\frac{359.42}{48 \times 21.2395}\right) \times 100=64.74
\end{aligned}
$$

$$
\text { Ref. [6]. }
$$

Spray water loss $=$ volume of water out sprinkler

- (volume of water reached/volume of water out sprinkler), volume of water out sprinkler $=\left(30 \mathrm{~min} * 60 * 0.5 * 4 / 1000=2.8 \mathrm{~m}^{2}\right.$, volume of water reached ground $=X * S * L=0.02123 * 7.5 * 10=1.5922 \mathrm{~m}^{3}$ Therefore

spray water losses $=((2.88-1.5922) / 2.88) * 100 \%=44.79 \%$ 


\section{Field work infiltration test}

By using double ring infiltrometer the following data was obtained.

Table 1: $\quad$ Infiltration data in study area.

\begin{tabular}{|c|c|c|c|}
\hline $\begin{array}{c}\text { Accumulated } \\
\text { depth mm } \\
\text { infiltration }\end{array}$ & Accumulated & $\begin{array}{c}\text { Accumulated } \\
\text { depth mm } \\
\text { infiltration }\end{array}$ & Accumulated \\
\hline mm infiltration & Time minute & mm infiltration & Time minute \\
\hline 0 & 0 & & 9 \\
\hline 0.5 & 2 & 3.1 & 11 \\
\hline 1 & 4 & 4.5 & 21 \\
\hline 1.2 & 5 & 5.1 & 6.8 \\
\hline 1.4 & 6 & 26 & 16 \\
\hline 1.5 & & & \\
\hline
\end{tabular}

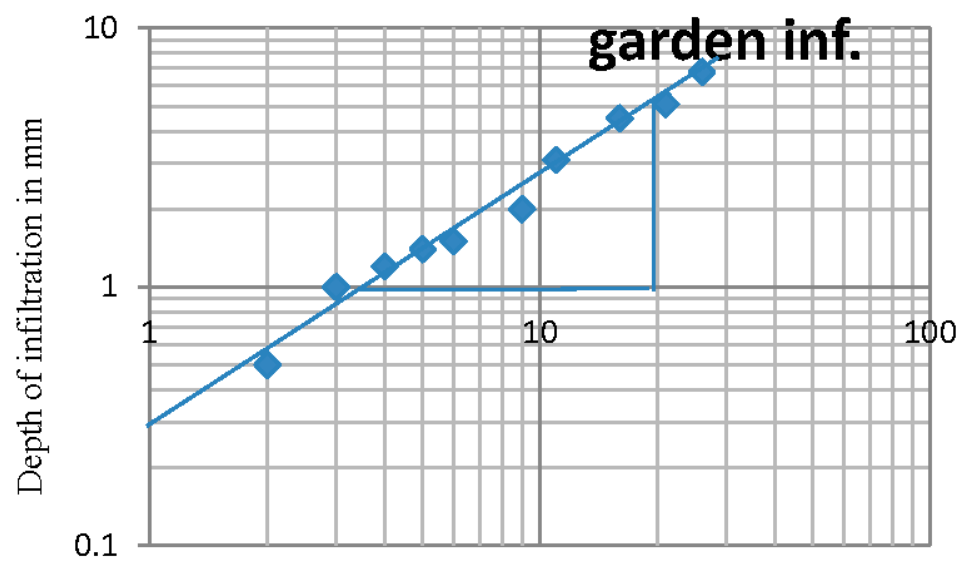

Figure 3: Data representation of infiltration. 


\section{Evaluation}

Deteminig the losses of water; in this case we note two type of losses - 1- losses due to surface runoff and 2- losses due to evaporation. At first, the surface runoff losses can be determined by the basic infiltration rate from fig. 3 .

$$
\begin{aligned}
& \mathrm{M}=0.95 \quad \mathrm{C}=0.3 \quad D=c T^{m} \quad \frac{d D}{d T}=m c T^{m-1} \quad \frac{d D}{d T}=I \\
& I=0.95 * 0.3 * 60^{-0.05} \\
& I=0.2322 \frac{\mathrm{mm}}{\text { minute }} \text { Infiltration rate } \mathrm{Tb}=600 n \\
& T b=600 * 0.05 \\
& T b=30 \text { minute } \quad I b=T b^{n} * c * m \quad I b=30^{-0.05} * 0.3 * 0.9 \frac{\mathrm{mm}}{\text { minute }} \\
& I b=30^{-0.05} * 0.3 * 0.9 * 60 \frac{\mathrm{mm}}{\text { hour }} \quad I b=14.42 \frac{\mathrm{mm}}{\text { hour }} \\
& I b=7.21 \frac{\mathrm{mm}}{\text { hour }}
\end{aligned}
$$

where: Ib=basic infiltration rate; $\mathrm{m}=$ slope of infiltration line; $\mathrm{T}=$ Time of infiltration.

\section{Discussion and conclusion}

Water losses can be found through

1- $\quad$ Losses due to surface runoff

Losses due to surface runoff $=$ water reached surface - basic infiltration rate

$$
21.23-7.21=14.02 \mathrm{~mm} \text { losses of runoff }
$$

2- $\quad$ Losses due to evaporation and spray

$$
\mathrm{Q}=0.5 \mathrm{~L} / \mathrm{s} \text { sprinkler water discharge }
$$

Losses due to evaporation and spray = volume of water out of the sprinklers volume of water reached surface

volume of water out of the sprinklers $=30$ minute $* 0.5 * 60 * 4 / 1000=3.6 \mathrm{~m}^{3}$

volume of water reached ground surface $=\mathrm{X} * \mathrm{~S} * \mathrm{~L}$

$$
=0.02123 * 7.5 * 10=1.5922 \mathrm{~m}^{3}
$$

Depth of water out of sprinklers $=3.6 /\left(7.5^{*} 10\right)=0.048 \mathrm{~m}=48 \mathrm{~mm}$.

In this case study

Total volume out of water =discharge of 4 sprinkler * time of operation

Depth of water out of sprinklers = total volume/study area

Depth of water out of sprinklers $=48 \mathrm{~mm}$

Depth of water reached ground surface $=21.23 \mathrm{~mm}$

Losses due to evaporation and spray $=48-21.23$

$$
=26.77 \mathrm{~mm}
$$

Therefore,

$$
\begin{gathered}
\text { total water losses }=14.02+26.77=40.79 \\
\text { depth of infiltration }=7.21 \mathrm{~mm}
\end{gathered}
$$


The results shows that the percentage of water losses $=40.79 / 48 * 100=84 \%$. So percentage of water used $=16 \%$.

\section{Recommendation}

1- For reducing the water losses of evaporation the irrigation must be in times that temperature less than $30^{\circ} \mathrm{C}$.

2- For reducing the water losses of surface runoff the discharge must reduced by $14.02 / 48 * 100=29 \%$.

3- For reducing the water losses of spray the water pressure must reduced to min permissible pressure.

\section{References}

[1] Haman, Z. and T. H. Yeager 2001. Field evaluation of container nurseries irrigation system uniformity of water application in sprinkler systems. Cooperative extension service. Institute of Food and Agricultural Sciences of Florida, Gainesville, 32611.

[2] Kara, T., Ekmekci, E. and Apen, M. 2009. Determining the uniformity coefficient and water distribution characteristics of some sprinklers. Department of Agricultural Structures and Irrigation Engineering, Ondokuz Mayis University, 55139, Kurupelit, Samsun, Turkey.

[3] Keller, J. 1990. Sprinkler and trickle irrigation. Van Nostrand, New York. USA.

[4] Keller, J. and R. D. Bliesner 1990. Sprinkler Irrigation. Van Nostrand, New York.

[5] King, B. A. and D. C. Kincaid 1998. Optimizing performance of pivot sprinkler packages. Irrigation business and technology feature. University of Idaho, USA.

[6] Hajim, Ahmed Youssef, Hakki Ismail Yassin 1992. Engineering Systems Field Irrigation, and the Ministry of Higher Education and Scientific Research, the University of Mosul, the National Library for Printing and Publishing.

[7] http://cursos.uc.cl/unimit_agl_014-1/almacen/1237929440_lgurovic_sec4_ pos0.pdf 